\title{
Schizachyrium maritimum gulf bluestem, maritime bluestem
}

\section{Poaceae}

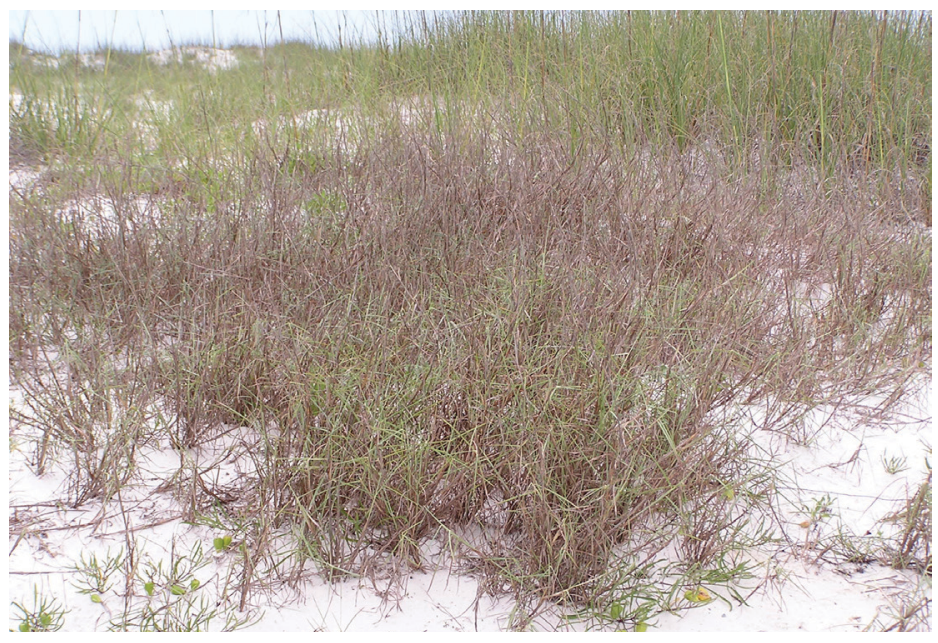

Credit: Josiah Raymer, UF/IFAS

Gulf bluestem occurs throughout the Florida Panhandle and in neighboring coastal states. Gulf bluestem helps stabilize dunes, forms thick stands in areas leeward of slopes (Craig 1991), replaces sea oats as the dominant species on protected foredunes behind a seaward ridge after 2 to 17 years (Johnson 1997), and occurs throughout flatwoods and disturbed areas. This plant is very closely related to little bluestem (Schizachyrium scoparium), and its taxonomic position is not entirely agreed upon by taxonomists; hence information may also be located using the taxonomic synonym Schizachyrium scoparium var. scoparium.

\section{General Description}

Gulf bluestem is a rhizomatous perennial grass with numerous crowded culms that reach heights of $1.5 \mathrm{ft}$. Leaves are clasping, sheathing, and flat at the base. They are up to 0.4 in wide and 6 in or more long, green or glaucous (chalky gray) with a bronze purple tinge. Ligules are 0.5 to $1 \mathrm{~mm}$ long. Culms are erect and, with age, the elongated culms become prostrate. Inflorescences are axillary and terminal, solitary

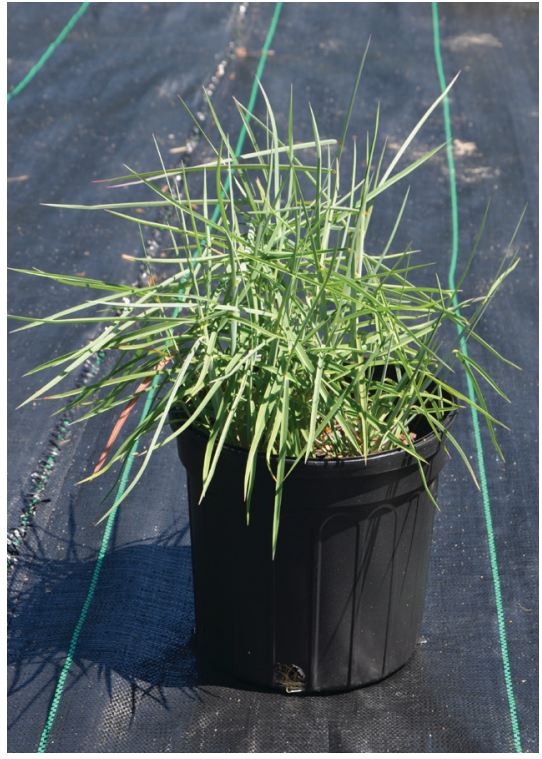

Credit: Gabriel Campbell, UF/IFAS racemes, with an inconspicuous rachis. Flowers are paired spikelets: a scabrous, 11-mm-long, sessile fertile spikelet, and a pedicellate, sterile or staminate, 10 -mm-long spikelet. Fruits are caryopses.

\section{Propagation}

Cutting propagation protocols are described by Thetford and Miller (2002, 2004). Collect cuttings from basal portions of elongated culms during the growing season. If plant material is limited, cuttings can be taken from material above the basal 4 in of shoots, but these cuttings will need auxin (1,000 ppm IBA (Indole-3-butyric acid)) applications and will have only limited success. Collection of cutting material from older portions of the culms is necessary to ensure mature nodes are present on the cutting material.

Place cuttings in 72-cell flats with a well-drained substrate under intermittent mist for 3 to 4 weeks under natural photoperiod. Remove rooted cuttings from mist and hand water as needed for an additional 1 or 2 weeks. Fertigate 1 to 2 times a week with $150 \mathrm{ppm} \mathrm{N}$ fertilizer. On week 5 or 6 transplant to 4 -in or 1-gal pots. Continue with container production for an addition 4 to 6 weeks to achieve a full rootball and a canopy of 6-8 in.

Propagation by seed is possible, but no published studies quantify optimal germination conditions or viability percentages. The authors have germinated field-collected seed in community flats with great success. However, it is noted that seeds appear to have an after-ripening requirement,

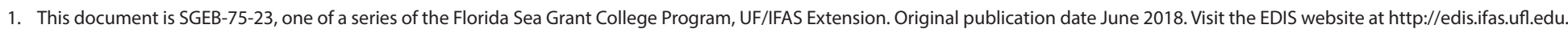

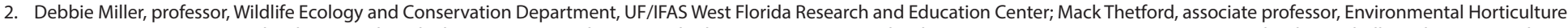

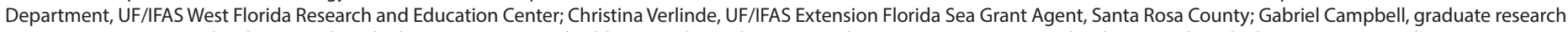

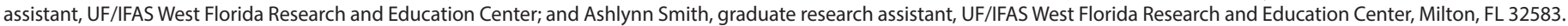


because initial germination does not occur under standard greenhouse germination conditions until 35 to 40 days after sowing. Gulf bluestem plants readily seed in nursery ground beds and in neighboring pots in outdoor research production areas in Milton, Florida.

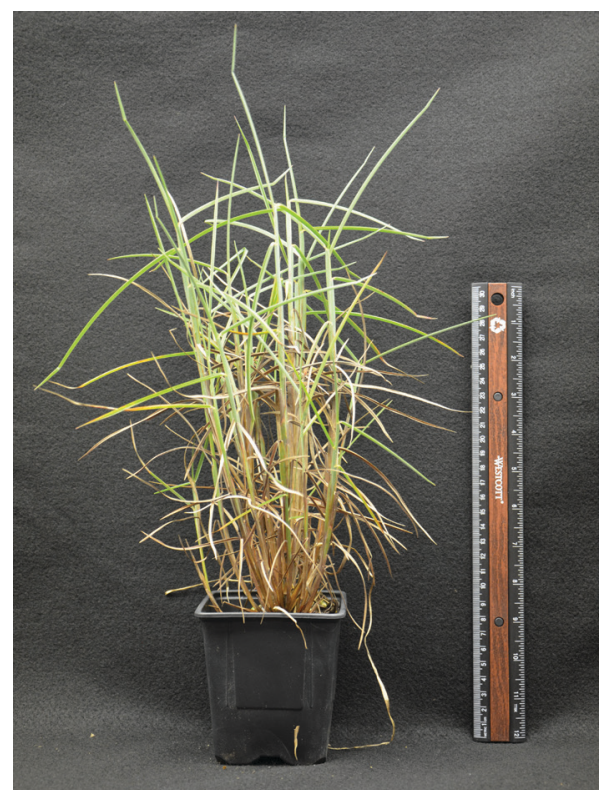

Credit: Gabriel Campbell, UF/IFAS

\section{Outplanting}

Gulf bluestem restoration planting should take place in the summer months, particularly June (Miller et al. 2008; 2014). Plants should be placed no closer than $130 \mathrm{ft}$ ( $328 \mathrm{ft}$ is the recommended distance) inland from the mean high tide line of the Gulf of Mexico from the foredunes into the coastal grassland and backdunes. Planting efforts in spring or fall have proven to result in high plant mortality because of sand loss and root exposure around transplants (Miller et al. 2014). Widely spaced transplants also are vulnerable to increased sand loss; therefore transplants should be no more than 12 in apart. Transplants are not detrimentally affected by sand burial but are susceptible to decreased survival from competition with other dune plants, particularly sea oats. Plants should be placed in areas with reduced wind exposure, such as areas with intact dunes, recovering dunes, or where the distance between barrier islands and mainland is reduced (Miller et al. 2008). Plantings with large contiguous areas will reduce the edge effect, which is deleterious for transplant survival in this species.

\section{Literature Cited}

Craig, R.M.1991. "Plants for coastal dunes of the gulf and south Atlantic coasts and Puerto Rico." USDA SCS. Agriculture Information Bulletin 460.

Johnson, A.F. 1997. "Rates of vegetation succession on a coastal dune system in northwest Florida." Journal of Coastal Research. 13(2):373-384.

Miller, D.L., M. Thetford, and M. Schneider. 2008. "Distance from the Gulf Influences Survival and Growth of Three Barrier Island Dune Plants." Journal of Coastal Research. 24(4A):261-266.

Thetford, M., and D. Miller. 2002. "Propagation of four Florida coastal dune species." Native Plants Journal. 3(2):112-120.

Thetford, M., and D. Miller. 2004. Propagation and production of Gulf bluestem. ENH-974. Gainesville: University of Florida Institute of Food and Agricultural Sciences. http://edis.ifas.ufl.edu/ep231

Miller, D.L., M. Thetford, J. Dupree, and L. Atwood. 2014. "Influence of seasonal changes and shifting substrate on survival of restoration plantings of Schizachyrium maritimum (Gulf bluestem) on Santa Rosa Island, Florida." Journal of Coastal Research. 30(2):237-247. 